\title{
«Монголофильство» политической элиты Тувинской Народной Республики
}

\author{
Иванна В. Отрощенко \\ Институт востоковедения им. А. Е. Крымского \\ Национальной академии наук Украины, Украина
}

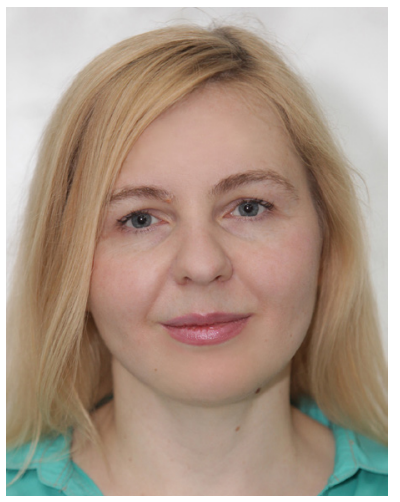

В статье исследуется один из аспектов политической истории Тувинской Народной Республики, который пока не получил освещения со стороны исследователей. В советском политическом дискурсе тувинских политиков того времени часто называли монголофилами, подразумевая под этим их симпатии к Монгольской Народной Республике, либо стремление присоединить Туву к Монголии. Сам термин использовался советской стороной только для характеристики настроений тувинской политической элиты (например, для описания настроений и деятельности политической элиты и интеллигенции в Бурят-Монголии активно использовался более известный термин «панмонголизм»).

Цель исследования - показать, что именно советские функционеры вкладывали в это понятие, кого и по каким критериям причисляли кмонголофилам, соответствовала ли такая характеристика действительности. Исследование опирается на документы (доклады, донесения, характеристики, переписка и т. д.), в том числе неопубликованные, которые хранятся в Российском государственном архиве социально-политической истории, в фонде 495 «Исполнительный комитет Коминтерна (ИККИ)».

Анализ документов показывает, что в советском политическом дискурсе и дискурсе Коминтерна, касающемся Тувы, термины «монголофильство», «монголофилы», «монголофильские настроения» часто фигурировали в 1920-е г2., изредка встречаясь в первой половине 1930-х г2. Из исторических событий того времени, темой, при освещении которой наиболее часто задействовался термин «монголофильство», стало Хемчикское восстание 1924 г. После его завершения одним из критериев монголофильства в глазах советской стороны стали контакты тувинских политиков с монгольскими инструкторами или с монгольским консульством в Туве. Одной из главных аксиом было утверждение, что монголофильские настроения тувинских политиков основывались на желании объединиться со знатью, ламством, феодалами и всеми имущими слоями МНР для уменьшения размаха революции Тувы, а идеологи монголофильства состояли исключительно из состоятельной тувинской знати.

Ключевые слова: Тувинская Народная Республика; история Тувы; СССР; Монголия; Монгольская Народная Республика; Коминтерн; монголофильство; монголофил; политическая элита; Монгуш Буян-Бадыргы; С. Оруйгу; М. Нимажап; тувинцы; монголы; Хемчикское восстание вания Тувы. 2020, № 3. С. 35-48. DOI: www.doi.org/10.25178/nit.2020.3.3

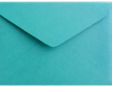

Отрощенко Иванна Витальевна - доктор исторических наук, ведущий научный сотрудник отдела современного Востока Института востоковедения им. А. Е. Крымского Национальной академии наук Украины, главный редактор журнала «Східний світ» («Мир Востока»). Адрес: 01001, Украина, г. Киев, ул. Грушевского, д. 4, к. 226. Эл. адрес: shidnyj.svit@gmail.com

OTROSHCHENKO, Ivanna Vitalievna, Doctor of History, Leading Research Fellow, Department of the Modern East, A. Yu. Krymskyi Institute of Oriental Studies, NAS of Ukraine; Editor-in-Chief, Shìdnij svì (Mir Vostoka). Postal address: Apt. 226, 4 Hrushevskyi St., 01001 Kyiv, Ukraine. Email: shidnyj.svit@gmail.com ORCID ID: 0000-0003-3508-7954 


\title{
"Mongolophilia" of the political elite in the Tuvan People's Republic
}

\author{
Ivanna V. Otroshchenko \\ A. Yu. Krymskyi Institute of Oriental Studies, National Academy of Sciences, Ukraine
}

\begin{abstract}
The article explores one aspect of the political history of Tuvan People's Republic, which has not been covered by the researchers yet. The Soviet political discourse often referred to Tuvan politicians as 'Mongolophilic', meaning that they were sympathetic to the Mongolian People's Republic or their commitment to align Tuva and Mongolia. The term was applied by the Soviets only to describe the political sentiments of the Tuvan elites (for instance, referring to the similar moods and orientation of the BuryatMongolian political elite and intelligentsia, they used a better-known term 'pan-Mongolism').

The aim of this article is to demonstrate what exactly the Soviet officials mean by 'Mongolophilia'; who could be classified as a Mongolophile; what criteria were used for that and if these characteristics were true. The research is based on documents (reports, dispatches, characteristics, correspondence etc.), including those not published and stored in the Russian State Archive of Socio-Political History, f. 495 'Executive Committee of the Comintern' (ECC).

Our analysis has shown that the terms 'Mongolophilia', 'Mongolophiles' and 'Mongolophilic sentiment' were used frequently in the Soviet and Comintern discourse of Tuva during the 1920s and the early 1930s. The terms were used most frequently to describe the Khemchik rebellion of 1924. Subsequently, the contacts between Tuvan politicians and Mongolian instructors or the Mongolian consulate in Tuva started to be seen by the Soviet officials as one of the criteria of 'Mongolophilia'. A major presupposition was that 'Mongolophilic' sentiments of Tuvan politicians were based on the desire of allying with the nobility, lamas, feudal lords and all wealthy circles of MPR to contain the revolution in Tuva, and that ideologists of Tuvan "Mongolophilia" all came from among the wealthy Tuvan nobles.
\end{abstract}

Keywords: Tuvan People's Republic; Tuvan history; USSR; Mongolia; Mongolian People’s Republic; Comintern; mongolophilia; mongolophil; political elite; Mongush Buian-Badyrgy; S. Oruigu; M. Nimazhap; Tuvans; Mongols; Khemchik rebellion

\section{For citation:}

Otroshchenko I. V. "Mongolofil'stvo" politicheskoi elity Tuvinskoi Narodnoi Respubliki [“Mongolophilia” of the political elite in the Tuvan People's Republic]. New Research of Tuva, 2020, no. 3, pp. 35-48. (In Russ.). DOI: www.doi. org/10.25178/nit.2020.3.3

\section{Введение}

В 1920-е гг. стремление к объединению с Монголией наблюдалось как среди представителей тувинской властной верхушки, так и среди населения разных хошунов Тувинской Народной Республики (THP). Об этом говорят петиции от хошунов Тувы того времени, выступления и предложения тувинских государственных деятелей, не говоря уже о лозунгах Хемчикского восстания 1924 г. ${ }^{1}$ Сторонников объединения с МНР насчитывалось достаточно много, включая отдельных премьер-министров и министров ТНР, а также секретарей ТНРП² (Mänchen-Helfen, 1931: 169; Friters, 1937: 328; Tang, 1959: 399 и т. д.). Тувинских политиков, представителей старой аристократии, чиновничества и духовенства, настроенных на объединение или сотрудничество с Монголией, в советском политическом дискурсе и дискурсе Коминтерна называли монголофилами.

В науке, да и в обществе, термин «монголофильство» сегодня чаще употребляют, характеризуя точку зрения евразийцев о влиянии монгольских завоеваний на российскую государственность и России как наследнице Монгольской империи и Золотой Орды ${ }^{3}$ («безудержное монголофильство и монголофильская ревизия русской истории» (Хоружий, 2008: 189)). Однако, в то время, когда «группа русских

\footnotetext{
${ }^{1}$ Нужно отметить, что в то же время имели место и петиции за самостоятельность Тувы (см.: Российский государственный архив социально-политической истории - далее РГАСПИ, ф. 495, оп. 153, ед. хр. 3, л. 94; Кайский, 2007: 563 и т. д.).

${ }^{2}$ ТНРП - Тувинская народно-революционная партия (1921-1944).

${ }^{3}$ Как писал один из главных теоретиков евразийства П. Н. Савицкий: «Своею ролью наказания Божия татары очистили и освятили Русь, своим примером привили ей навык могущества, - в этом противоположении явлен двойственный лик России. Россия - наследница Великих Ханов, продолжательница дела Чингиса и Тимура, объединительница Азии» («Степь и оседлость» (1922 г.)) (Савицкий, 2003: 691).
} 
эмигрантов-интеллектуалов, обосновавшаяся в Праге, стала уделять монголам более пристальное внимание» (Схиммельпеннинк ван дер Ойе, 2002/2003: 26), этот же термин в более приземленной плоскости начал задействоваться в советской и коминтерновской документации, которая касалась Тувы. Интересно, что использовался он советской стороной преимущественно для характеристики ${ }^{1}$ настроений тогдашней тувинской политической элиты, ориентированной на объединение с Монголией ${ }^{2}$ (в то время как для описания настроений и деятельности политической элиты и интеллигенции в Бурят-Монголии активно использовался более известный термин «панмонголизм» (см., напр.: РГАСПИ, ф. 89, оп. 4, ед. хр. 162, л. 72)). И хотя советская дипломатия и номенклатура, по-видимому, просто позаимствовали оба термина из документального наследия Российской империи, в этой дифференциации наблюдается своя логика. Яркие представители бурятской интеллигенции, ставшие монгольскими политическими деятелями, такие как Ц. Жамцарано и Э.-Д. Ринчино, мечтали о консолидации, в той или иной степени, всей этнографической Монголии. Тогда как у многих представителей тувинской элиты 1910-1920-х гг. были менее амбициозные планы - вернуть прежний порядок вещей, добиться возвращения Тувы в состав Монголии.

Цель исследования - показать, что именно советские функционеры вкладывали в это понятие, кого и по каким критериям причисляли к монголофилам, соответствовала ли такая характеристика действительности. Этот аспект политической истории ТНР пока не получил освещения со стороны тувиноведов. Исследование опирается на документы (доклады, донесения, характеристики, переписка и т. д.), в том числе неопубликованные, которые хранятся в Российском государственном архиве социально-политической истории, в фонде 495 «Исполнительный комитет Коминтерна (ИККИ)».

\section{Оппозиция «монголофилы - русофилы» в период протектората}

В период протектората, когда российские управленцы стали внимательнее присматриваться к краю, который попал под их покровительство, эпитет монголофилов применялся в первую очередь к тем представителям тувинской знати, которых подозревали в контактах с властями Монголии. А их было немало.

Рассмотрим в качестве примера ситуацию с правителем Оюннарского хошуна, амбын-нойоном Комбо-Доржу (Гомбодоржи), инициатором российского протектората над Урянхайским краем. Он в свое время рассчитывал с российской помощью восстановить свои права на Тоджинский, Салчакский, Хазутский хошуны и перейти постепенно к единому управлению краем. Не встретив поддержки в своем вопросе и чувствуя все большее давление и вмешательство, амбын-нойон теряет веру в Россию и постепенно начинает разделять взгляды своего сына, О. Соднам-Бальчыра, который тяготел к Монголии ${ }^{3}$ (Shurkhuu, 2014: 138). В конце концов, новый комиссар по делам Урянхайского края В. Ю. Григорьев решил сместить Комбо-Доржу за то, что тот резко изменил свое отношение к русским и не удержал подвластных территорий. Произошло это в августе 1915 г. Избранный населением 18-летний сын амбын-нойона Соднам-Бальчыр сначала отказался от выполнения возложенных на него обязанностей, ссылаясь на свою молодость и неопытность. Затем в сопровождении нескольких человек он уехал в Ургу, чтобы выяснить там вопросы управления хошунов и подданства тувинцев. В результате Комбо-Доржу и его сына обвинили в монголофильстве. На должность правителя Оюннарского хошуна был назначен лояльный России Агвандемчиг (Агван Шарып), что привело к резкому обострению обстановки в крае. В. Ю. Григорьев характеризовал Агвандемчига как «искреннего русофила, умного, просвещенного и влиятельного человека» (цит. по: История Тувы, 2007: 34).

Через 20 лет, рассказывая об Урянхае времен протектората, Р. Кабо, советский экономист и географ, преподаватель Коммунистического университета трудящихся Востока, в частности, иронически описывал ситуацию с нойоном Салчакского хошуна: «...предстояло покорить два восточных хошуна: Сажакский и Тожинский, нойоны которых до тех пор отказывались признать русскую власть. В первую очередь была проведена операция над салжакским нойоном по превращению его из “монголофила” в

\footnotetext{
${ }^{1}$ В таком же значении термин «монголофилы» используется и некоторыми современными российскими исследователями, специализирующимся на истории Тувы (см.: Моллеров, 2005, 2015; Хертек, 2016 и др.), и иногда встречается в тематических словарях (Словник ..., 2019: 38).

2 1911-1924 - Внешняя Монголия, с 1924 г. (до 1992 г.) - Монгольская Народная Республика (МНР).

${ }^{3}$ При объявлении о принятии Урянхайского края под российское покровительство тувинцев обязали воздерживаться от самостоятельных контактов с Монголией и другими государствами (см.: Тувагийн туухэнд ... , 2014: 89).
} 
“руссофила”. Продержав его под арестом целый месяц, Григорьев добился своего, после чего нойон был отпущен домой с наказом, как ему следует себя впредь вести» (Кабо, 1934: 182).

Российские чиновники сокрушались о том, что, несмотря на все выгоды русского управления, тувинцы массово благодаря своей инертности, в вопросах политического подчинения слепо следуют за отдельными нойонами и чиновниками, «руководимыми в данном случае побуждениями личного честолюбия и материальными выгодами» (Сводка сведений ..., 1917: 57). Отмечалось, что эти руководители находили к тому же благодарную почву в недоверии к русским и опасении за участь своих земель, вызванных неосторожными действиями некоторых чинов. Иркутский генерал-губернатор Л.М.Князев полагал, что «для... окончательного закрепления нашего влияния потребуется вдальнейшем лишь воздействие на упорствующих в своем монголофильстве урянхайских чиновников, а также установление фактического контроля над путями сообщения в Монголию, дабы воспрепятствовать неразрешенным отлучкам туда урянхайских чиновников и нойонов, и пресечь появление в крае монгольских агитаторов» (там же: $57-58$ ).

20 июня 1919 г., когда разгоралось первое Хемчикское восстание (История Тувы, 2007: 95-99), начальник Штаба Иркутского военного округа в своем рапорте писал: «Положение дел в Урянхае постоянно осложняется Монголо-Китайскими интригами. В настоящее время продолжается восстание на реке Кемчик и в районе границы с Монголией. Восстание само по себе незначительно, но все же требует принятия энергичных мер к подавлению. В дальнейшем вследствие постоянных интриг монголофилов-нойонов и пропаганды русских большевиков возможность восстаний ни в коем случае не может быть исключена» (Государственный архив Российской Федерации - далее ГА РФ, ф. p-200, оп. 1, д. 496, л. 9-9 об).

В монголофильстве также обвинялось и тувинское ламство. Подчиненность тувинского буддийского духовенства иерархам, стоящим во главе соседней державы и считающим Туву частью Монголии, тесные связи между двумя народами на почве общей религии, образования и медицины, в данном случае также связанных с буддийской монастырской культурой, становились политическим фактором. Так, комиссар В. Григорьев в своем письме иркутскому генерал-губернатору (26 ноября 1916 г.) указывал, что большинство тувинских лам обучалось в столице Монголии - Урге и получало там дальнейшее продвижение по церковной иерархии. И поэтому буддийское духовенство, имеющее на массы тувинцев огромное влияние, «является чрезвычайно деятельным и распыленным проводником монголофильства» (Собрание архивных ..., 2014: 241). В. Ю. Григорьев отмечал, что для наиболее успешного и прочного освоения Урянхая и прекращения постоянного и малополезного для «российского дела» в крае общения тувинских лам с Ургою, представляется необходимым создание в Урянхае автономного относительно Монголии духовенства - подобно тому, как это имеет место в Забайкалье или в калмыцкой степи. В этом (и не только) вопросе антагонистом автору видится фигура «русофила почтенного Гебши Хамбо Гелын Ламы Чжамсо» (ГА РФ, ф. p-200, оп. 1, д. 494, л. 54 об). Настоятеля Верхне-Чаданского хурэ Лопсана Чамзы (Лубсана Чжамцо) комиссар Григорьев предлагал как человека искренне преданного российскому делу, человека выдающейся энергии, очень умного и достаточно авторитетного, чтобы надлежащим образом организовать под руководством российских властей дело управления буддийским духовенством Урянхая (Собрание архивных ..., 2014: 241-242). В то время как большинство тувинской элиты склонялось к присоединению к Монголии, Лопсан Чамзы на протяжении всех 1910-х гг. оставался убежденным сторонником сближения с Россией. Как видно, из довольно схожих характеристик Агван-Шырапа и Лопсана Чамзы, данных В. Григорьевым и приведенных выше, видим, что первым пунктом указывается преданность и симпатия к России претендентов. Это являлось, по-видимому, решающим фактором, определяющим выбор этих кандидатур.

Оппозиция «русофилы - монголофилы» (где-то восходящая к концептуальной оппозиции «свой чужой»), заложенная во времена протектората в политическом дискурсе Российской империи, в несколько измененном виде сохранилась и в раннем советском политическом дискурсе, касающемся политических событий в ТНР ${ }^{1}$. Слово «русофилы» звучало реже, хотя и встречалось (см.: РГАСПИ, ф. 495,

\footnotetext{
${ }^{1}$ Одним из примеров может служить характеристика нойона Тоджинского хошуна Тонмита (1922 г.) «Туммут к русскому населению особой симпатии не питает, но, считая русских сильным народом, интересуется ими и вообще событиями в России. Большой монголофил, часто совершает поездки в глубь Монголии на поклон святым и т. д. Весьма уважает, относится с большим пиететом к Джалхандзе-хутухте. Революционности в Туммуте мало; горячий сторонник монгольской ориентации» (РГАСПИ, ф. 495, оп. 152, ед. хр. 16, л. 71).
} 
оп. 153, ед. хр. 26, л. 5). Согласно веяниям времени, его заменили другие определения: например, «крепкий кадр сознательно, идейно ориентирующихся на СССР людей», левые и т. д. Добавилось и новое определение - «националист», чаще всего относящееся к тувинским правым и носившее на первых порах в глазах советской стороны положительный оттенок (по-видимому, потому, что «националисты» считались сторонниками существования независимой Тувы). Одним из определяющих факторов, позволяющих отнести тувинского политика в ту или иную группу, оставалась его лояльность - теперь уже к Советскому Союзу либо к Монголии.

\section{Советский политический и Коминтерновский дискурсы о развитии монголо- фильства}

Советские и Коминтерновские представители, работавшие или посещавшие Туву в 1920-е гг., фиксировали в своих отчетах тогдашние «монголофильские настроения» в тувинском обществе, сводя их, как правило, к проискам классовых врагов. Основные события, носившие монголофильскую окраску, приходились, по их мнению, на первую половину 1920-х гг. Речь шла о Хемчикском восстании и последовавших за ним петициях тувинских хошунов о присоединении к Монголии.

B. Мачавариани, представитель КИМа ${ }^{1}$ на IV съезде тувинского ревсомола ${ }^{2}$, отмечал, что с 1921 по 1924-1925 гг. в Туве господствовали «монголофильские настроения», определяя, в частности, и политику СССР. По его мнению, Хемчикское восстание 1924 г. было заключительным аккордом в борьбе монголофильских группировок за присоединение Тувы к Монголии: «После кемчугского восстания и нашей довольно значительной работы в Туве, монголофильские настроения пошли на убыль, а сейчас мы наблюдаем даже обратное явление» (РГАСПИ, ф. 495, оп. 153, ед. хр. 35, л. 1). В чем состояла «значительная работа», можно узнать из другого документа - справки «Тува», датированной 2 февраля 1929 г. ${ }^{3}$ : «Наша реальная поддержка культурно-экономических начинаний Тувпра ${ }^{4}$, ликвидация монгольской агрессии и, наконец, быстрый рост экономического благосостояния Тувы за последние годы - все это парализовало деятельность монголофильских элементов страны и консолидировало силы ее около популярного и осознанного уже широкими массами лозунга независимости» (РГАСПИ, ф. 508, оп. 3, ед. хр. 5, л. 41).

М. Сафьянов, который в первой половине 1920-х гг. работал в советском торгпредстве в Туве, со своей стороны, считал, что после 1925 г. (имеется в виду договор между Тувой и СССР ${ }^{5}$ «все монголофильськие настроения испарились даже у тех, кто за несколько месяцев до этого подавал петиции о присоединении к Монголии» (Кайский́ ${ }^{6}$ 2007: 563).

Более пространно эта же позиция излагается представителем Коминтерна в Туве С. А. Нацовым (1926-1927). В 1921-1925 гг. «в Танну-Туве имели место так называемые "монголофильские настроения"»; тувинские феодалы, ламство и кулацкие слои аратского населения активно противодействовали политике партии на выделение Танну-Тувы в самостоятельное государство и стремились превратить ее в один из северных аймаков Монголии, всячески дискредитировать в глазах аратского населения идею национальной независимости (Нацов, 1930: 101-102). Некоторые из них, будучи в руководстве партии и правительства, умышленно доводили до абсурда налоговое обложение, ложащееся на бедняцко-середняцкие аратские хозяйства. Исходя из привычного нарратива классовой борьбы, С. Нацов рассказывал, как тувинские феодалы и чиновники стремились объединиться с феодально-теократическими кругами Монголии, чтобы общими силами затормозить победоносную аратскую революцию. Эти попытки «вылились в монголофильских петициях, посылаемых со всех мест феодально-чиновничьими элементами, сидевшими в аппаратах партийных организаций и местных самоуправлений» (там же: 102). Первенство авторства всех этих петиций принадлежало феодальночиновничьим кругам Хемчика.

\footnotetext{
${ }^{1}$ КИМ - Коммунистический интернационал молодежи.

${ }^{2} \mathrm{IV}$ съезд ТРСМ открылся 24 декабря 1928 г.

${ }^{3}$ Авторство неизвестно (см.: РГАСПИ, ф. 508, оп. 3, ед. хр. 5, л. 35-42).

${ }^{4}$ Тувпра - тувинское правительство.

522 июля 1925 г., во время пребывания в Москве первой тувинской правительственной делегации, было заключено соглашение между СССР и Народной Республикой Танну-Тува. Оно оформило дружеские отношения между двумя странами; было решено обменяться официальными дипломатическими представительствами.

${ }^{6}$ Кайский - псевдоним М. Г. Сафьянова.
} 
Когда стало очевидным, что аратские массы, вопреки грубейшим искривлениям линии партии (по налоговому и другим вопросам), не пошли за феодалами и чиновниками, стремящимися взорвать национально-революционную власть, те, которые до этого времени ратовали за упразднение правительства и присоединение к Монголии, несколько умолкли и стали менять тактику своих действий. «Некоторые из монголофильских элементов на словах согласились с фактом самостоятельного существования народно-революционного правительства идажеизъявили готовность работать в аппаратах центральных и местных органов власти» (там же: 103). Но сделали это с целью изнутри ослабить движение аратских масс, притупить революционный характер политики партии и правительства, исказить основную линию партии, рассчитанную на некапиталистическое развитие страны.

Как покажет дальнейшее изложение, «монголофильские настроения» в тувинском обществе не исчезли после завершения Хемчикского восстания и сопровождавшей его волны петиций о присоединении тех или иных тувинских хошунов к МНР. Последняя такая петиция (по крайней мере, известная автору) была в 1930-м г. (Собрание архивных ..., 2014: 319). Далее последовали целенаправленные переселения тувинцев на монгольскую территорию, которые продолжались десятки лет. По мнению автора, такое развитие событий, в частности, стало следствием осознания тувинцев, что петиции и обращения к властям о желательности объединения с монголами ни к чему не приведут. В начале 1930-х гг. в ТНР снова произошли антиправительственные выступления, где звучали и промонгольские лозунги, ликвидировать которые тувинской власти удалось только при прямом содействии СССР (больше см.: Отрощенко, 2012).

\section{Хемчикское восстание 1924 г. и его последствия}

В исследуемых дискурсах темой, при освещении которой наиболее часто задействовался термин «монголофильство», стало Хемчикское восстание 1924 г., которое в советской документации иногда прямо называли «монголофильским восстанием» ${ }^{1}$ (см.: РГАСПИ, ф. 508, оп. 3, ед. хр. 5, л. 40). В одном из документов, датируемых 1929 г., утверждалось, что революционные изменения в Туве встретили огромное сопротивление со стороны «феодальных, старо-чиновничьих, ламских и зажиточных кругов населения» (РГАСПИ, ф. 508, оп. 3, ед. хр. 5, л. 39). В противовес лозунгу независимости страны эти элементы выбросили лозунг присоединения Тувы к Монголии, аргументируя его тем, что Монголия близка тувинцам по религии, быту, социальному устройству и что маленькому тувинскому народу не под силу содержать самостоятельный государственный аппарат и что «декларированный Совпра $^{2}$ отказ от Урянхая есть лишь замаскированный способ прибрать его снова к русским рукам. Эта монголофильская агитация феодалов, кулаков и лам нашла себе активную поддержку в кругах Монгольской Народной Партии» (МНП) и монгольского правительства, которые «открыто обвиняли нас в империализме и требовали ликвидации Тувинского правительства и присоединения Тувы к Монголии» (РГАСПИ, ф. 508, оп. 3, ед. хр. 5, л. 39). Далее в документе пишется, что положение в Туве обострилось до того, что в 1924 г. «монголофильские элементы», использовав ошибки налоговой работы молодого тувинского правительства, его экономические затруднения, ошибки советской торговой работы и недостаточно выдержанные взаимоотношения исполкома РСТК с тувинским правительством, начали

\footnotetext{
${ }^{1} \mathrm{~B}$ «Истории Тувы» для описания этих событий употребляется термин «мятеж», само восстание характеризуется как «антигосударственное выступление на Хемчике» (История Тувы, 2007: 152). Российские исследователи среди причин восстания справедливо называют государственно-налоговую эксплуатацию, модернизацию традиционного тувинского общества, движение за объединение с Монголией (Саая, Сат, 2006: 149). По мнению некоторых западных исследователей, публично высказанное желание (без предварительного разрешения из Москвы) объединить всех монголов и связанные с ними народы в едином государстве вместе с социальным недовольством, кажется, стали главными причинами этого восстания (см.: Bebler, 1987: 33; Mänchen-Helfen, 1931: 169; Friters, 1937: 328; Tang, 1959: 416 и др.). В частности, О. Менхен-Хельфен писал: «Когда они поднимались в 1924 году в Хемчикском районе, они действовали не только ради спасения женских кос. Они снова прогоняли торговцев, на этот раз российских государственных торговцев. Они провозглашали присоединение к Монголии. Вероятно, они знали, что Монголия находилась под господством русских, однако не под таким непосредственным, отягчающим как Тува. Они хотели в Монголию, и монголы хотели принять их с радостью» (Mänchen-Helfen, 1931: 167).

${ }^{2}$ Совпра - советское правительство.

${ }^{3}$ В феврале 1922 г. в Кобдо (Монголия) были созданы две новые административные должности представителей ургинского правительства, в частности, сайда (сановника), который занимался внутренними вопросами, связанными с Кобдоским округом.
} 
при активной поддержке монгольских властей (в лице кобдоского сайда ${ }^{3}$ ) вооруженное восстание против правительства Тувы под лозунгом присоединения к Монголии. «Благодаря военным и дипломатическим усилиям СССР это восстание было ликвидировано ${ }^{1}$; советская сторона приняла ряд мер по упорядочению своей тувинской работы (см.: РГАСПИ, ф. 508, оп. 3, ед. хр. 5, л. 40).

В СССР полагали, что монгольская агитация, несомненно, сыграла большую роль в Хемчикском «антиправительственном восстании», «организованном монголофильским чиновничеством и ламством» (РГАСПИ. Ф. 508, оп. 3, ед. хр. 5, л. 125). Также утверждалось, что идеологи монголофильства и Хемчикского восстания состояли исключительно из имущей знати Тувы (РГАСПИ, ф. 495, оП. 153, ед. хр. 30, л. 198). При этом советский советник тувинского правительства П. Медведев, свидетель тех событий, утверждал, что во время Хемчикского восстания один М. Буян-Бадыргы, премьер ТНР, сдерживал напор «монголофильского потока» и требовал решительной расправы с повстанцами (РГАСПИ, ф. 495, оп. 153, ед. хр. 3, л. 72). В более поздних документах, где упоминалось это восстание, термин «монголофильство» уступил место «панмонголизму». К примеру, в 1934 г. писали, что «эти контрреволюционные, феодально-теократические элементы под лозунгом “панмонголизма” в 1924 году подняли контрреволюционное восстание против национальной революции» (см.: РГАСПИ, ф. 495, оп. 153, ед. хр. 67).

На II Великом Хурале ТНР (в сентябре 1924 г.) впервые делегаты осудили «монголофильское влияние» в правительстве и руководстве ТНРП. Считается, что тогда из состава правительства были выведенынаиболее активные монголофилы. На решениеделегатов осмещении сдолжности главыправительства М. Буян-Бадыргы повлияло письмо бывшего министра юстиции Тувы, вышеупомянутого О. Соднам-Бальчыра, в котором Буян-Бадыргы бездоказательно назывался организатором восстания (История Тувы, 2007: 332). Премьер-министром и министром иностранных дел на II Великом Хурале был избран С. Оруйгу. По мнению монгольского исследователя Д. Шурхуу, после прекращения Хемчикского восстания влияние Монголии в Туве не уменьшилось, а, наоборот, укрепились позиции таких монголофилов как Дондук ${ }^{2}$, Нимажап ${ }^{3}$, Шагдыр ${ }^{4}$, которые считались лидерами правых (Шурхуу, 2001: 114).

Такой вывод подтверждается словами П. Медведева, который считал, что монголофильские группировки взяли верх в 1924 году, и именно поэтому Буян-Бадыргы оставил государственную службу. Это заставило его изменить отношение к монголам (РГАСПИ, ф. 495, оп. 153, ед. хр. 3, л. 72). Во время Хемчикского восстания «Буян-Бадыргы один сдерживал напор монголофильских тенденций, поддерживаемый Тондуком ${ }^{5}$ и они сдали свои позиции, потому что мы разошлись с ними в вопросе методов подавления восстания. Буян-Бадыргы настаивал на вооруженном разгроме банд, а мы избрали мирный путь ликвидации и впоследствии стали гладить по головке их противников. С тех пор они стали на сторону монголофильского течения, в этом была наша ошибка», - писал П. Медведев в одной из своих характеристик ${ }^{6}$ (РГАСПИ, ф. 495, оп. 153, ед. хр. 3, л. 69). Тут нужно подчеркнуть, что ха-

\footnotetext{
${ }^{1}$ Хемчикское восстание продолжалось около полугода. Его завершению способствовало прибытие полномочных представителей СССР и МНР в июле 1924 г. в Кызыл, проведение ряда консультаций и переговоров, совещания в августе с представителями тувинских хошунов. Во время совещаний с представителями населения обсуждалась проблема налогов (которые наконец-то решили снизить), утеснения в религиозной сфере, принудительная отправка девушек в школы, заявление Тес-Хемского и Салчакского хошунов с просьбой о присоединении Тувы к Монголии. На этих совещаниях был принят ряд решений и сделаны разъяснения и заявления. Организаторы восстания были арестованы, но впоследствии тувинские власти отпустили их на свободу. Уголовные дела против них были приостановлены (больше об этих событиях см.: Отрощенко, 2011: 136-158).

${ }^{2}$ К. Дондук в 1925-1927 гг. возглавлял правительство ТНР.

${ }^{3}$ М. Нимажап - глава Президиума Малого Хурала ТНР (1925-1929). В «Справке о Тувинской Народной Республике», составленной по материалам 3-го Дальневосточного отдела НКИД и датированной 11 апреля 1943 г., Нимажапа даже называют премьером ТНР и руководителем Хемчикского восстания 1924 г. (Архив внешней политики Российской Федерации - далее АВП РФ, ф. 06, оп. 5, п. 31, д. 364, л. 18).

${ }^{4}$ М. Шагдыр в октябре 1924 г. избран главой ЦК ТНРП, занимал эту должность в течение года.

${ }^{5}$ Имеется в виду К. Дондук - первый председатель Президиума Малого Хурала ТНР (1923-1925), затем премьер. По словам одной из характеристик, во время Хемчикского восстания 1924 г. подвергался аресту со стороны повстанцев, но впоследствии ими же был освобожден (РГАСПИ, ф. 495, оп. 153, ед. хр. 28, л. 66).

${ }^{6}$ Характеристики чаще всего не были датированы, архивное дело, в котором содержатся выше процитированные характеристики: «Доклад в Восточный отдел ИККИ об итогах 4 съезда Танну-Тувинской НРП (1-й экз.)», датируется 18 ноября 1925 г. (см.: РГАСПИ, ф. 495, оп. 153, ед. хр. 3).
} 
рактеристики на тувинских политиков, составленные советскими представителями в Туве в 1920-е гг., имеют большое значение для данного исследования и ниже будут много цитироваться. Практически в каждой из них внимание заострялось на отношении характеризуемого лица к Хемчикскому восстанию 1924 г.; последнее, таким образом, выступает, своего рода точкой отсчета и ключевым критерием для оценки политического деятеля.

Одним из критериев монголофильства в глазах советской стороны были контакты тувинских политиков с монгольскими инструкторами и монгольским полпредством в Туве. Тут необходимо сделать небольшое отступление. В 1924 г., признавая, что невозможно при отсутствии осведомленных лиц поставить партийную работу на надлежащий уровень, ЦК ТНРП обратился в Коминтерн и ЦК МНРП с просьбой прислать инструкторов. Улан-Батор отправил в Туву двоих инструкторов - Найдансурэна и Доржпалама, которые некоторое время помогали ЦК ТНРП в его работе (РГАСПИ, ф. 495, оп. 153, ед. хр. 3, л. 9).

Заподозренными в монголофильстве, в частности, из-за непродолжительных контактов с монгольскими инструкторами были премьер ТНР С. Оруйгу, глава ЦК ТНРП Шагдыр, секретарь ЦК Наримандах. Так, в характеристике на Шагдыра советский советник ЦК ТНРП П. Медведев писал:

«В начале Шагдыр был мнения необходимости своей самостоятельности, очевидно поскольку это возглавлял Буян-Бадыргы, впоследствии же когда... одержала верх точка зрения Нимоджапа за присоединения Танну-Тувы к Монголии, Шагдыр изменил свой взгляд и стал сторонником монголофильского течения. Причем проводил это дипломатично, скрывая от нас и льстя нам. За время пребывания здесь инструкторов всецело подпал под их влияние вплоть до враждебности к нашему парторгану во главе с тов. Чугуновым. Перед монголами льстил, заискивал и ухаживал за ними. Испугавшись выступления в ЦК партии т. Чугунова ${ }^{1}$ изменил свои действия в вопросе монголофильства и в остальных вопросах в лучшую для нас сторону. В настоящее время открыто не проявляет монголофильства, а также внешне легко поддается нашему влиянию» (РГАСПИ, ф. 495, оп. 153, ед. хр. 3, л. 76).

Еще одну показательную характеристику П. Медведев составил на секретаря ЦК ТНРП Наримандаха (Нармандагы). В ней сообщалось, что Наримандах в 1924 г. занимал должность секретаря министерства финансов и был одним из хорошо образованных представителей Тувы. Во время Хемчикского восстания ему поручили пробраться в тыл повстанцев и разложить их, тем самым способствуя ликвидации мятежа.

«Но вместо этого Наримандых, попав в тыл повстанцев, стал одним из руководителей повстанцев и взял на себя задание поехать во главе делегации в Ургу с целью присоединить Урянхай к Монголии и распустить Правительство. Этот поступок выявил Наримандыха как предателя, страдающего монголофильством в самой острой форме. Вернувшись обратно и увидя, что из его затеи ничего не вышло, он занял примирительную позицию к нам, но ничуть не сдал своей Монголофильской ${ }^{2}$ политики. Во время пребывания Монгольских инструкторов здесь находился в самой тесной связи с ними, все что слышал от консула передавал срочно им. В настоящее время занимает должность секретаря ЦК... в отношение монголофильства в душе остается таким же» (РГАСПИ, ф. 495, оп. 153, ед. хр. 3, л. 77).

Советские представители, как могли, боролись с таким «прискорбным» явлением как монголофильство. Еще в первом квартале 1925 г. С. Оруйгу был снят с должности премьера. Преемником Оруйгу на посту премьера стал К. Дондук. За время своей стремительной политической карьеры он неоднократно выступал за присоединение Тувы к Монголии (больше см.: Отрощенко, 2015).

Ha IV съезде ТНРП (14-19 октября 1925 г.) в новый состав ЦК не попали ни бывший глава ЦК ТНРП Шагдыр, ни секретарь ЦК Наримандах. «Как определенные монголофилы, они были нами провалены», - сообщал коминтерновец А. М. Амур-Санан, курировавший подготовку этого съезда

\footnotetext{
${ }^{1}$ Секретарь Районного бюро РКП(б) Я. Чугунов заявил, что действия тувинского правительства все время идут неверным и реакционным путем и это является следствием постоянных тайных контактов с монгольскими инструкторами. Мол, премьер С. Оруйгу постоянно с ними общается и бывает у них на дому. Напрасно последние оправдывались, что не руководили действиями тувинских властей, не направляли их против РСТК, а также не склоняли тувинское правительство присоединиться к Монголии (РГАСПИ, ф. 144, оп. 1, ед. хр. 175, л. 7; больше об этой ситуации см.: Отрощенко, 2011: 153-156). Несмотря на все приведенные аргументы, весной 1925 г. монголы вынуждены были уехать домой. Уполномоченный Коминтерна в МНР Т. Рыскулов убедил монгольское руководство отказаться от посылки нового инструктора в Туву и вообще - не вмешиваться в дела последней до общего разрешения вопроса (РГАСПИ, ф. 495, оп. 152, ед. хр. 34, л. 15).

${ }^{2} \mathrm{C}$ большой буквы написано в документе.
} 
(РГАСПИ, ф. 495, оп. 153, ед. хр. 3, л. 87). При этом, характеризуя новый состав ЦК, П. Медведев писал: «Что же касается монголофильства, то это течение существует или по своей доброй воле, или же в силу необходимости, т. к. монголофильские группировки одержали верх в 1924 г. Но этот состав является наиболее объективным, это все лучшее, что мы можем найти в данном случае» (РГАСПИ, ф. 495, оп. 153, ед. хр. 3, л. 69). Шли поиски соответствующих кадров. Так, П. Медведев указывал, что под левыми группировками нужно подразумевать действительно революционно настроенную часть беднейшего населения с ориентацией на СССР, настроенную решительно против монголов. Советник добавлял, что, к сожалению, среди них нет ни одного грамотного человека. Эту группу можно использовать в интересах дела, но стать самостоятельным руководящим центром она не сможет (РГАСПИ, ф. 495, оп. 153, ед. хр. 3, л. 110). По мнению А. М. Амур-Санана, чтобы иметь в дальнейшем крепкую базу для влияния на Танну-Тувинскую Республику, необходимо бы из среды самих тувинцев создать крепкий кадр сознательно, идейно ориентирующихся на СССР людей. Как показывает дальнейшее развитие событий, со временем это советской стороне удалось.

\section{Монголофильские настроения в Туве во второй половине 1920-х г2.}

Однако и после IV съезда THРП вопрос монголофильства тувинской элиты продолжал беспокоить коминтерновских функционеров. Так, 18 ноября 1925 г. в своем докладе Восточному отделу Коминтерна А. Амур-Санан писал:

«Монголофильство еще очень сильно. Реакционное чиновничество (Нимаджап, Ширап ${ }^{1}$ и др.), которое еще играет политическую роль, всю свою политическую, идеологическую симпатию отдает Монголии. Ко всему русскому относятся с плохо скрываемой враждебностью. Мучительно ищут пути, каким бы образом разрешить проблему полной эмансипации Танну-Тувы от СССР, хотя их никто теперь не угнетает и не притесняет. Так Ширап (Минфин) в беседе со мной неоднократно трактовал вопрос о праве наций на самоопределение, вытекающем, как говорил он, из самого существа Октябрьской Революции. Однажды он сказал: “Ведь Польша воспользовалась этим правом и окончательно отделилась от России. Нельзя ли то же самое нам?” (РГАСПИ, ф. 495, оп. 153, ед. хр. 3, л. 86 б.).

А потом, вздохнув, продолжал:

«А было когда-то и у нас хорошо, когда не было русских колонистов, но это было 58 лет тому назад» (РГАСПИ, ф. 495, оп. 153, ед. хр. 3, л. 86 б).

По словам А. Амур-Санана, М. Нимажап (Мининдел) и его группа свое отрицательное отношение к СССР строили на спекуляции на якобы русификаторской политике последнего, - доказательством этому служила РСТК. Упразднение же последней ${ }^{2}$ и создание вместо нее хошуна выбило из-под ног благодарную для агитации против СССР и за Монголию почву. Амур-Санан подчеркивал, что прошлое насилие и теперешнее поведение части колонистов дают почву резко отрицательному отношению ко всему русскому (РГАСПИ, ф. 495, оп. 153, ед. хр. 3, л. 86б-87; см. также: л. 105). В справке под названием «Русская колония в Туве» ${ }^{3}$ написанной несколько позже, дается любопытное объяснение привилегированного положения РСТК в Туве:

«После образования ТНР в силу того, что фактически свободу для Тувы завоевали красные партизаны Русской Колонии ${ }^{4}$, мы должны были согласиться удовлетворить решительное их требование полной правовой и экономически-культурной самостоятельности. К этому нас побуждала и неустойчивость политического положения молодой Тувинской Республики в первые годы ее существования, слабость Тувправительства, проявление агрессивности Монголправительства и вызванное с этим монголофильское движение среди состоятельной феодальной верхушки тувинцев» (РГАСПИ, ф. 508, оп. 3, ед. хр. 5, л. 45).

Подчеркивалось, что особое положение советских граждан в Туве породило множество всяческих столкновений с тувинцами и тувинской администрацией, вызывало подчас недоброжелательство в отношении СССР и монголофильские настроения (см.: РГАСПИ, ф. 495, оп. 153, ед. хр. 37. л. 5).

\footnotetext{
${ }^{1}$ С. Нацов называл М. Нимажапа и Ширапа в своих донесения «двумя столпами монголофильского чиновничества» (13 ноября 1926 г.) (РГАСПИ, ф. 495, оп. 153, ед. хр. 5, л. 114).

${ }^{2}$ Только в мае 1932 г. РСТК была преобразована в комитеты советских граждан.

${ }^{3}$ «Русская колония в Туве. (Справка)» (см.: РГАСПИ, ф. 508, оп. 3, ед. хр. 5, л. 43-46). Этот документ идет в деле сразу за справкой «Тува», датированной 2 февраля 1929 г. Справка об РСТК тоже относится к концу 1920-х, возможно, - к началу 1930-х гг. и, скорее всего, принадлежит представителю Коминтерна В. А. Богданову.

${ }^{4}$ Разумеется, такое утверждение упрощенное и субъективное.
} 
Аналогичные соображения в свое время (20 августа 1926 г.) высказывал и представитель Коминтерна при ЦК ТНРП С. А. Нацов, заключая:

«По моему глубокому убеждению мы недостаточно учли того обстоятельства, что самовыпячивание роли русской колонии со стороны РСТК, не только не улучшило, но и наоборот ухудшило постановку всей нашей работы в Танну-Туве. Отношение тувинцев к нам было не особенно дружелюбное, они от времени до времени посматривали на своего южного соседа - Монголию» (РГАСПИ, ф. 495, оп. 153, ед. хр. 5. л. 105).

По мнению С. Нацова, перелом в настроениях тувинцев произошел только с приездом нового советского полпреда - А. Г. Старкова, который сумел наладить отношения с правительством ТНР.

Кто принадлежал к националистам в этот период (по мнению советской стороны), мы узнаем из характеристик, составленных полпредом СССР А. Старковым в 1928 г. Как националиста полпред характеризовал премьера К. Дондука (РГАСПИ, ф. 495. оп. 153, ед. хр. 28, л. 66). Заметим, что несколько позже, в объяснительной записке относительно собственной «антипартийной деятельности», К. Дондук отмечал: «Мысль о том, что я в 3 году, будучи главой Малого хурала, разделял мнение министров Оруйгу и Нимажап про присоединение Тувы к Монголии, что свое мнение письменно оформил - это правильно. Свое мнение о присоединении Тувы к Монголии я ни от кого не скрывал» (цит. по: Саая, Сат, 2006: 154). Относительно заместителя Дондука - Т. Талха-Сюрюна указывалось, что ранее, будучи представителем хошуна, он осаждал правительство грамотами о том, что народ его хошуна выражает желание присоединиться к Монголии. Оговаривалось, что в силу торговых отношений Т. Талха-Сюрюн имеет связь с Монголией, но «за последнее время придерживается национального толка» (РГАСПИ, ф. 495 , оп. 153, ед. хр. 28, л. 67). Из характеристики на Буян-Бадыргы мы узнаем, что он принимал участие в ликвидации Хемчикского восстания, «но в то же время имел связь с повстанцами», а также «придерживался монголофильского толка» (РГАСПИ, ф. 495, оп. 153, ед. хр. 28, л. 67). Буян-Бадыргы характеризовали как человека, способного «быстро ориентироваться и применяться к местности и положению, времени», и который в последнее время примыкает к национальному течению (РГАСПИ, ф. 495, оп. 153, ед. хр. 28, л. 67).

Как указывалось выше, определение «националист», в это время, применительно к тувинской ситуации, в глазах советской стороны носило положительный оттенок, в противовес монголофилам и идее присоединения Тувы к МНР. Однако и Дондук, и Талха-Сюрюн ранее были рьяными сторонниками присоединения к Монголии. Сложно сказать, насколько были справедливы упреки в монголофильстве Буян-Бадыргы. Тувинские нойоны, к которым принадлежал Буян-Бадыргы, в 1910-е гг., бывало, меняли свои политические предпочтения. Не всегда был последователен в своих симпатиях к российской стороне и сам Буян-Бадыргы ${ }^{1}$, внимательно следивший за изменениями политической обстановки. Горячий сторонник независимой Тувы на первых порах, в дальнейшем мог и поменять свое мнение, в частности под влиянием Хемчикского восстания 1924 г., которое продемонстрировало явное недовольство его бывших подданных новыми реалиями. Напомним, что Хемчикские хошуны, на территории которых развернулось восстание, представляли большинство жителей Тувы, и в 1921 г. именно позиция их правителей стала определяющей для провозглашения независимости.

Представители Коминтерна продолжали внимательно наблюдать за контактами тувинских политиков с монгольским полпредством. Характеризуя осложнившуюся на рубеже 1920-1930-х гг. ситуацию на монгольско-тувинской границе, 17 декабря 1931 г. в Восточный секретариат, в частности, доносили следующее:

«После пограничного инцидента и представленного Мининделом проекта резолюции... я прихожу к выводу, что некоторые руководящие товарищи считали необходимым производить нажим на Монголию путем инспирирования пограничных инцидентов, на словах ведя политику сугубой лояльности и взывая к поддержке СССР. В то время как т. Данжай² вносит довольно ультимативные проекты резолюции, он сам поддерживает исключительно интимные взаимоотношения с монгольским полпредом, в ряде случае

\footnotetext{
${ }^{1}$ Больше см.: ГАРФ, ф. р-200, оп. 1, д. 498, л. 84-84об.; д. 499, л. 72, 93 и т. д. В частности, в 1919 г. временно исполняющий обязанности начальника штаба Иркутского округа, полковник Главацкий телеграммой сообщал следующее: «Нойон Кемчикского Та-Хошуна Гунбуян-Батарху и Ойнарский нойон Сотном-Балчзир открыто встали сторону Монголии Китая и бежали Монголию, пример этот может оказаться заразительным для других князей нойонов Урянхая (ГА РФ, ф. р-200, оп. 1, д. 499, л. 93).

${ }^{2}$ Данжай - министр иностранных дел (1929-1931), далее - председатель Госплана ТНР.

${ }^{3}$ Тувполпредство - Полномочное представительство ТНР в МНР (1928-1944).

${ }^{4}$ ГВО Монголии - Государственная внутренняя охрана МНР.
} 
даже конспирируя от членов Политбюро. Больше того, в секретари прав-ва и секретарем по переписке Мининдела т. Данжай выдвинул б. секретаря Тувполпредства ${ }^{3}$ в Монголии, которого уличают в том, что он имеет очень тесную связь с ГВО 4 Монголии и является агентом последнего, каковое обстоятельство им тщательно скрывается. Получается, с одной стороны, очень развитый местный национализм, с другой, явное монголофильство» (РГАСПИ, ф. 495, оп. 153, ед. хр. 44, л. 103).

О. Менхен-Хельфен, посетивший в те годы Туву, саркастично замечал: «Я упреждаю следующее: никакого упрека тувинский политик не должен опасаться так, как укора дружбы с монголами. Это сразу неприятно поражает» (Mänchen-Helfen, 1931: 18).

Еще в начале 1929 г. в результате прихода к власти в ТНР левых были выведены из состава Политбюро ЦК ТНРП и лишились власти вышеупомянутые Т. Талха-Сюрюн, М. Буян-Бадыргы, Наримандах (который на тот момент возглавлял Тувинценкоп), Шагдыр, Нимажап и др. Советская сторона не скрывала, что именно «усилиями нашего обновленного советнического аппарата» удалось сделать первый шаги к объединению тувинской левой оппозиции, выработке ее программы (РГАСПИ, ф. 508, оп. 3, ед. хр. 5, л. 41). В одном из документов 1930 г. «активные деятели... монголофильского движения» упоминаются среди «непреданных революции элементов». В этом же ряду стояли нойоны, эксплуататоры, спекулянты, скупщики, ламы-шаманы, взяточники, растратчики, активные деятели Хемчикского восстания (по-видимому, 1924 г.) и «другие им подобные элементы» («Инструкция по проведению проверки и чистки рядов ТНРП») (РГАСПИ, ф. 495, оп. 153, ед. хр. 41, л. 27-32).

Восстания начала 1930-х гг. в ТНР ускорили трагическую развязку. Так, заседание Политбюро ЦК ТНРП 22 марта 1932 г. обсудило вопрос «О контрреволюционных бандитско-грабительских участниках группы и злоупотреблении своим служебным положением, умышленно принимавших участие в Хемчикском восстании черно-желтых феодалов Буян-Бадыргы, Дондука, Шагдыра, Бойду» (цит. по: Ховалыг, 2007: 63-64). Фигуранты огульно обвинялись «в частых мятежах против существующего социального порядка вкупе с “правыми” оппортунистами» (цит. по: История Тувы, 2007: 199). Заседание решило утвердить проект постановления УГВПО ${ }^{1}$, где предлагалось приговорить обвиняемых к расстрелу. В числе этих 19 опальных политиков были расстреляны также М. Нимажап, Т. Талха-Сюрюн и Наримандах (Иргит, 2019: 88-90).

\section{Заключение}

Анализ документов показывает, что в советском политическом дискурсе и дискурсе Коминтерна, касающемся Тувы, термины «монголофильство», «монголофилы», «монголофильские настроения» активно использовались в 1920-е гг., изредка встречаясь в первой половине 1930-х гг. Из исторических событий того времени, темой, при освещении которой наиболее часто задействовался термин «монголофильство», стало Хемчикское восстание 1924 г. После его завершения одним из критериев монголофильства в глазах советской стороны были контакты тувинских политиков с монгольскими инструкторами или с монгольским консульством в Туве. Одной из главных аксиом было утверждение, что монголофильские настроения тувинских политиков основывались на желании объединиться со знатью, ламством, феодалами и всеми имущими слоями МНР для уменьшения размаха революции Тувы, а идеологи монголофильства состояли исключительно из состоятельной тувинской знати.

Советская сторона была вынуждена временно мириться с такими «нежелательными» настроениями ряда представителей тувинской политической элиты, потому что на первых порах их некем было заменить. С другой стороны, поначалу не исключалась вероятность присоединения Тувы к Монголии в перспективе. Появление в ТНР «левых» - молодых людей, получивших образование в СССР, носителей нового мировоззрения, позволило распрощаться с временными попутчиками, которые быстро перешли в разряд «классовых врагов», а затем стали страницей истории, о которой на десятилетия постарались забыть.

\section{СПИСОК ЛИТЕРАТУРЫ}

Иргит, О. Ю. (2019) Политические репрессии в Тувинской Народной Республике в 1921-1944 гг.: дисс. ... к-та ист. наук. Кызыл. 213 с.

История Тувы (2007) / под ред. В. А. Ламина. Новосибирск : Наука. Т. II. 430 с.

1 УГВПО - Управление Государственной Внутренней Политической Охраны. 
Кабо, Р. (1934) Очерки истории и экономики Тувы. М. ; Л. : Гос. соц.-экон. изд-во. Ч. 1. 203 с.

Кайский, М. (2007) Урянхайский вопрос // Урянхай. Тыва дептер: антология научной и просветительской мысли о древней тувинской земле и ее насельниках, об Урянхае - Танну-Туве, урянхайцах - тувинцах, о древностях Тувы: в 7 т. / составитель: С. К. Шойгу. М. : Слово. Т. 5. Урянхайский край: от Урянхая к Танну-Туве (конец XIX - первая половина XX в.). 736 с. С. $552-563$.

Моллеров, Н. М. (2005) Советско-тувинские отношения: 1917-1944 гг.: дисс. ... д-ра ист. наук. М. 465 с.

Моллеров, Н. М. (2015) Позиции СССР и Внешней Монголии по «урянхайскому вопросу» в первой четверти $\mathrm{XX}$ века // Россия и Монголия в первой половине XX века: концептуальные вопросы российско-монгольских отношений (дипломатия, экономика, наука) : сборник статей. Улан-Батор; Иркутск : Изд-во БГУ. Кн. 5.416 с. C. 221-230.

Нацов, С. (1930) Правая опасность в Тувинской народно-революционной партии // Жизнь Бурятии. № 1. C. 101-108.

Отрощенко, І. В. (2011) На шляху до Великої Монголії (панмонгольський рух у 1920-1930-ті роки). Київ : Інститут сходознавства ім. А. Ю. Кримського. 456 с. (На укр. яз.).

Отрощенко, И. В. (2012) Из истории протестного движения в ТНР первой половины 1930-х гг. [Электронный ресурс]// Новые исследования Тувы, № 3. URL: https://nit.tuva.asia/nit/article/view/315 (дата обращения: 28.04.2020).

Отрощенко, И. В. (2015) Из истории взаимоотношений ТНР и МНР: проблема возвращения “части тувинского народа” [Электронный ресурс] // Новые исследования Тувы. № 3. С. 27-40. URL: https:/nit.tuva.asia/nit/article/ view/4/4 (дата обращения: 28.04.2020).

Саaя, С. В., Сат, С. Ч. (2006) Геополитический статус Тувы в первой половине XX века (1911-1944 годы). Абакан : Хакасское книжное издательство. 293 с.

Савицкий, П. Н. (2003) Степь и оседлость // Классика геополитики. ХХ век : сб. ст. / сост. М. М. Королев. М. : ООО «Издательство АСТ». 736 с. С. 688-699.

Сводка сведений военно-статистического отделения Штаба Омского военного округа о Западном Китае и Монголии (Улясутайский округ, Кобдоский округ, Синьцзян и Алтайский округ). За первую половину 1917 года (1917). Омск : Тип. Штаба Омск. в. о. 73 с.

Словник «Урянхайско-тувинской энциклопедии» (2019) / ТРОО «Мир тувинцев». Кызыл : б. и. 388 с.

Собрание архивных документов о протекторате России над Урянхайским краем - Тувой: к 100-летию исторического события (2014) / сост.: Т. А. Бондаренко. Кызыл : ТИГИ. 479 с.

Схиммельпеннинк ван дер Ойе, Д. (2002/2003) Азиатский соблазн России // Космополис. № 2. С. 19-32.

Тувагийн туухэнд холбогдох архивын баримдын эмхэтгэл. Боть III (1921-1944) = Собрание архивных документов по истории Тувы. Том III (1921-1944) = Тыванын тоогузунге хамааржыр шыгжамырлар бижимелдеринин чыындызы. Том III (1921-1944) (2014) / гл. ред. С. Чулуун, А. К. Бичелдей. Уланбаатар ; Кызыл : б. и. 418 с. (На монг., рус. и тув. яз.).

Хертек, Л. К. (2016) Тувинско-монгольские связи и отношения в период Тувинской Народной Республики [Электронный ресурс] // Новые исследования Тувы. № 3. С. 65-81. URL: http://nit.tuva.asia/nit/article/view/464 (дата обращения: 28.04.2020).

Ховалыг, С. (2007) Личность в истории: Монгуш Буян-Бадыргы (1892-1932) // Вестник Евразии. № 2 (36). С. $42-71$.

Хоружий, С. (2008) Русский философ в Литве: a case study // Русский Міръ. № 1. С. 186-199.

Шурхуу, Д. (2001) Урянхайский вопрос в монголо-российских отношениях в первой четверти ХХ века // Россия и Монголия: новый взгляд на историю взаимоотношений в XX веке / редкол.: Алтанцэцэг Н. и др. М. : ИВ РАН. 276 с. C. 97-117.

Bebler, A. (1987) Conflicts between Socialist States // Journal of Peace Research. Vol. 24, No. 1. Pp. 31-46. DOI: https:// doi.org/10.1177/002234338702400104

Friters, G. M. (1937) The Development of Outer Mongolian Independence // Pacific Affairs. Vol. 10. No. 3. P. $315-336$. DOI: https://www.doi.org/10.2307/2751345

Mänchen-Helfen, O. (1931) Reise ins Asiatische Tuwa. Berlin : Der Bücherkreis g.m.b.h. 172 p.

Shurkhuu, D. (2014) Similarities and Differences between Mongolia and Tuva in the Evolution of Bilateral Ties // Oirat People: Cultural Uniformity and Diversification / Edited by I. Lkhagvasuren and Yuki Konagaya. Osaka : Senri Ethnological Studies (SES). Pp. 127-144. DOI: http://doi.org/10.15021/00002408 
Tang, P. S. H. (1959) Russian and Soviet Policy in Manchuria and Outer Mongolia. 1911-1931. Durham, N. C. : Duke University Press. xx, 494 p.

Дата поступления: 5.06.2020 2.

\section{REFERENSES}

Irgit, O. Yu. (2019) Politicheskie repressii v Tuvinskoi Narodnoi Respublike v 1921-1944 gg. [Political repressions in the Tuvan People's Republic in 1921-1944]: Diss. ... Candidate of Politic Sciences. Kyzyl. 213 p. (In Russ.).

Istoriia Tuvy [The History Of Tuva] (2007): in 3 vols. / ed. by V. A. Lamin. Novosibirsk, Nauka. Vol. 2. 430 p. (In Russ.).

Kabo, R. (1934) Ocherki istorii i ekonomiki Tuvy [Essays on the history and economy of Tuva]. Moscow, Leningrad, Gos. sots.-ekon. izd-vo. 203 p.

Kaiskii, M. (2007) Uriankhaiskii vopros [The Uriankhai issue]. In: Uriankhai. Tyva depter: antologiia nauchnoi i prosvetitel'skoi mysli o drevnei tuvinskoi zemle i ee nasel'nikakh, ob Uriankhae - Tannu-Tuve, uriankhaitsakh - tuvintsakh, o drevnostiakh Tuvy [Uriankhai: The Tuva Notebook: An anthology of research and educational thought on the ancient land of Tuva and its population, on Uriankhai - Tannu-Tuva, Uriankhaians - Tuvan people, and on the antiquities of Tuva], in 7 vols. Comp. by S. K. Shoigu. Moscow, Slovo. Vol. 5: Uriankhaiskii krai: ot Uriankhaia $k$ Tannu-Tuve [Uriankhai territory: from Uriankhai to Tannu-Tuva (late XIX - first half of XX century)]. 736 p. Pp. 552-563. (In Russ.).

Mollerov, N. M. (2005) Sovetsko-tuvinskie otnosheniia: 1917-1944 gg. [Soviet-Tuvan relations: 1917-1944]. Diss.... Doctor of History. Moscow. 465 p. (In Russ.).

Mollerov, N. M. (2015) Pozitsii SSSR i Vneshnei Mongolii po "uriankhaiskomu voprosu" v pervoi chetverti XX veka [The positions of the USSR and Outer Mongolia on the "Urikhay issue" in the first quarter of the 20th century]. In: Rossiia i Mongoliia v pervoi polovine XX veka: kontseptual'nye voprosy rossiisko-mongol'skikh otnoshenii (diplomatiia, ekonomika, nauka) [Russia and Mongolia in the first half of the 20th century: conceptual issues of Russian-Mongolian relations (diplomacy, economics, science)]. Ulan-Bator, Irkutsk, Izd-vo BGU. Book 5. 416 p. Pp. 221-230. (In Russ.).

Natsov, S. (1930) Pravaia opasnost' v Tuvinskoi narodno-revoliutsionnoi partii [Right-wing threat in the Tuvan People's Revolutionary Party]. Zhizn'Buriatii, no. 1, pp. 101-108. (In Russ.).

Otroshchenko, I. V. (2011) Na shlyakhu do Velykoyi Monholiyi (panmonhol's'kyy rukh u 1920-1930-ti roky) [On the way to great Mongolia (pan-Mongolian movement in 1920s-1930s)]. Kyiv, Institut skhodoznavstva im. A. Yu. Krimskogo. 456 p. (In Ukr.).

Otroshchenko, I. V. (2012) Iz istorii protestnogo dvizheniia v TNR pervoi poloviny 1930-kh gg. [About the history of protest movement in People's Republic of Tuva in the first half of 1930s]. New Research of Tuva, no. 3 [on-line] Available at: https://nit.tuva.asia/nit/article/view/315 (access date: 28.04.2020). (In Russ.).

Otroshchenko I. V. (2015) Iz istorii vzaimootnoshenii TNR i MNR: problema vozvrashcheniia "chasti tuvinskogo naroda" [From the history of People's Republic of Tuva and People's Republic of Mongolia mutual relations: the issue of returning "the part of Tuvan people"]. New Research of Tuva, no. 3, pp. 27-40 [on-line] Available at: https://nit.tuva.asia/ nit/article/view/4 (access date: 28.04.2020). (In Russ.).

Saaia, S. V. and Sat, S. Ch. (2006) Geopoliticheskii status Tuvy v pervoi polovine XX veka (1911-1944 gody) [Geopolitical status of Tuva in the first half of the twentieth century (1911-1944)]. Abakan, Khakass book publishing house. 293 p. (In Russ.).

Savitskii, P. N. (2003) Step' i osedlost' [Steppe and Settlement]. In: Klassika geopolitiki, XX vek [Classics of Geopolitics, XX Century]. Moscow, OOO “Izdatel'stvo AST". 736 p. Pp. 688-699. (In Russ.).

Svodka svedenii voenno-statisticheskogo otdeleniia Shtaba Omskogo voennogo okruga o Zapadnom Kitae i Mongolii (Uliasutaiskii okrug, Kobdoskii okrug, Sin'tszian i Altaiskii okrug). Za pervuiu polovinu 1917 goda [A summary of the information of the military-statistical department of the Headquarters of the Omsk Military District on Western China and Mongolia (Ulyasutai District, Kobdo District, Xinjiang and Altai District). For the first half of 1917] (1917). Omsk, Tip. Shtaba Omsk. v. o. 73 p. (In Russ.).

Slovnik "Uriankhaisko-tuvinskoi entsiklopedii" [Vocabulary of the Uryankhay-Tuva Encyclopedia] (2019). TROO "Mir tuvintsev". Kyzyl, s. n. 388 p. (In Russ.).

Sobranie arkhivnykh dokumentov o protektorate Rossii nad Uriankhaiskim kraem - Tuvoi: $k$ 100-letiiu istoricheskogo sobytiia [A collection of archival documents on Russian protectorate over Uriankhai Krai - Tuva: the 100th anniversary of the historical event] (2014). Compl.: T. A. Bondarenko and al. Kyzyl, s. n. 479 p. (In Russ.).

Schimmelpenninck van der Oye, D. (2002/2003) Aziatskii soblazn Rossii [Russia’s Asian temptation]. Kosmopolis, no. 2, pp. 19-32. (In Russ.). 
Tuvagiin tuukhend kholbogdokh arkhivyn barimdyn emkhetgel. Bot' III (1921-1944) = Sobranie arkhivnykh dokumentov po istorii Tuvy. Tom III (1921-1944) = Tyvanyn tooguzunge khamaarzhyr shygzhamyrlar bizhimelderinin chyyndyzy. Tom III (1921-1944) [A collection of archival documents on the history of Tuva. Vol. 3 (1921-1944] (2014) / ed. by S. Chuluun and A. K. Bicheldei. Ulanbaatar; Kyzyl, s. n. 418 p. (In Mong., Russ. and Tuv.).

Khertek, L. K. (2016) Tuvinsko-mongol'skie sviazi i otnosheniia v period Tuvinskoi Narodnoi Respubliki [TuvanMongolian relations and links under the People's Republic of Tuva]. New Research of Tuva, no. 3, pp. 65-81 [on-line] Available at: http://nit.tuva.asia/nit/article/view/464 (access date: 28.04.2020). (In Russ.).

Khovalyg, S. (2007) Lichnost' v istorii: Mongush Buian-Badyrgy (1892-1932) [A person in history: Mongush BuyanBadyrgy (1892-1932)]. Vestnik Evrazii, no. 2 (36), pp. 42-71. (In Russ.).

Khoruzhii, S. (2008) Russkii filosof v Litve: a case study [Russian philosopher in Lithuania: a case study]. Russkii Mir, no. 1, pp.186-199. (In Russ.).

Shurkhuu, D. (2001) Uriankhaiskii vopros v mongolo-rossiiskikh otnosheniiakh v pervoi chetverti XX veka [Uryanhay issue in Mongolian-Russian relations in the first quarter of the twentieth century]. In: Rossiia i Mongoliia: novyi vzgliad na istoriiu vzaimootnoshenii $v$ XX veke [Russia and Mongolia: a new look at the history of relations in the XX century]. Editor: Altantsetseg N. et al. Moscow, IV RAN. 276 p. Pp. 97-117. (In Russ.).

Bebler, A. (1987) Conflicts between Socialist States. Journal of Peace Research, vol. 24, no. 1, pp. 31-46. DOI: https:// doi.org/10.1177/002234338702400104

Friters, Gerard M. (1937) The Development of Outer Mongolian Independence. Pacific Affairs, vol. 10, no. 3, pp. $315-336$. DOI: https://www.doi.org/10.2307/2751345

Mänchen-Helfen, O. (1931) Reise ins Asiatische Tuwa. Berlin, Der Bücherkreis g.m.b.h. 172 p. (In Germ).

Shurkhuu, D. (2014) Similarities and Differences between Mongolia and Tuva in the Evolution of Bilateral Ties. In: Oirat People: Cultural Uniformity and Diversification / Ed. by I. Lkhagvasuren and Yuki Konagaya. Osaka, Senri Ethnological Studies (SES). Pp. 127-144. DOI: http://doi.org/10.15021/00002408

Tang, P. S. H. (1959) Russian and Soviet Policy in Manchuria and Outer Mongolia. 1911-1931. Durham, N. C., Duke University Press. xx, 494 p. 